\title{
Marine mammal research and conservation in China
}

KAIYA ZHOU

College of Life Sciences, Nanjing Normal University, 122 Ninghai Road, Nanjing 210097, China (kyzhounj@jlonline.com)

SUMMARY: Forty species of marine mammals have been reported from Chinese waters. Studies on systematics and taxonomy, morphology, and conservation biology of Chinese marine mammals are briefly reviewed. Brief accounts of systematic and taxonomic studies on Lipotes, Neophocaena, Tursiops, Sousa and Delphinus are included. Studies of gene sequences of Lipotes and other river dolphins in recent years support ranking Lipotidae as a family. The studies of structure and function were mainly on Lipotes and Neophocaena. The researches on conservation biology of Lipotes, Neophocaena, Sousa and other marine mammals in the past decades have provided scientific bases for conservation actions. Natural resenves for Lipotes and Neophocaena, Sousa, Dugong and Phoca largha were established.

\section{KEY WORDS: Marine mammals, Research and conservation, China}

\section{INTRODUCTION}

China is bordered by the Bohai, Yellow, East China and South China Seas. The extensive coastal waters of China are inhabited by a large number of marine mammals. The Chinese marine mammals include representatives in three mammalian orders. ${ }^{1)}$ The cetacean fauna contains 9 of the world's 14 cetacean families and 25 of the 34 genera, among which Lipotidae is endemic. Published literature indicates that 34 species of cetaceans have been reported from Chinese waters. The marine carnivores fauna contains 2 of the world's 3 pinniped families but only 4 of the 16 genera. Only 5 species of pinnipeds have been recorded from Chinese waters. The Sirenia are represented by a single species, Dugong dugon (Table 1).

\section{Systematics and taxonomy}

The baiji or Chinese river dolphin (Lipotes vexillifer) was previously classified as either in the family Platanistidae or in Iniidae. Zhou et $a l^{2,3)}$ established the new family Lipotidae for it based on osteological studies and anatomy of the stomach. Barnes ${ }^{4}$ recognized a fossil, Parapontoporia, as morphologically intermediate between Pontoporia and Lipotes and placed Lipotes and the fossil taxon each in a subfamily of Pontoporiidae. Conversely, de Muizon $^{5)}$ placed the fossil taxon with Lipotes in Lipotidae, and recent authors ${ }^{6,7)}$ followed de Muizon to rank Lipotidae as a family. Studies of the nucleotide sequences from mitochondrial cytochrome $b, 12 S$ and $16 \mathrm{~S}$ rRNA genes and two nuclear genes indicated that non-platanistid river dolphins, Lipotes, Inia and Pontoporia, are the extant representatives of early lineages that diverged from the stem leading to delphinoids, supporting their ranking as separate families. ${ }^{8-11)}$ Therefore, Lipotidae should be ranked as a family rather as a subfamily of Pontoporiidae.

Three populations of the finless porpoise (Neophocaena phocaenoides) are recognized in Chinese waters. Specimens from the Yangtze River are referred to the Yangtze population, those from the Yellow Sea, Bohai Sea and East China Sea to the Yellow Sea population, and those from the South China Sea and southern part of the East China Sea to the South China Sea population. In light of the morphological and mtDNA RFLP results, Gao and Zhou suggested that each of the three populations

Table 1 Number of genera and species in the families of Chinese marine mammals

\begin{tabular}{lcc}
\hline Order and family & $\begin{array}{c}\text { Number of } \\
\text { genera }\end{array}$ & $\begin{array}{c}\text { Number of } \\
\text { species }\end{array}$ \\
\hline CETACEA & 1 & 1 \\
Balaenidae & 2 & 7 \\
Balaenopteridae & 1 & 1 \\
Eschrichtiidae & 1 & 1 \\
Physeteridae & 1 & 2 \\
Kogiidae & 3 & 4 \\
Ziphiidae & 14 & 17 \\
Delphinidae & 1 & 1 \\
Phocoenidae & 1 & 1 \\
Lipotidae & & \\
SIRENIA & 1 & 1 \\
Dugongidae & & 2 \\
CARNIVORA & 2 & 3 \\
Otariidae & 2 & \\
Phocidae & & \\
\hline
\end{tabular}


should be assigned to a separate subspecies, i.e. Neophocaena phocaenoides phocaenoides for the South China Sea population, N. p. sunameri for the Yellow Sea population, and $N$. p. asiaeorientalis for the Yangtze population. The Yangtze population is the only known freshwater population of the finless porpoise. $^{12,13)}$

The occurence of Tursiops truncatus and $T$. aduncus in Chinese waters was reported by Zhou and Qian $^{14)}$ in 1985. T. aduncus differs from T. truncatus in having dark spots on the ventral surface between flippers and anus, shorter total body length, relatively longer beak and larger flipper. The former also differs from the latter in having shorter condylobasal length and obvious premaxillary convexity from lateral view of the rostrum. ${ }^{15)}$ The recognition of the two species is supported by external and osteological morphology and mtDNA analysis. ${ }^{16-18)}$

Zhou et $a .^{19)}$ thought that the differences between the Sousa populations in the Indian and Pacific Oceans warranted treating them as separate species, $S$. plumbea and $S$. chinensis, respectively. They were listed by Ross et al. ${ }^{20)}$ and Rice ${ }^{6)}$ as valid species, but most recent authors have recognized only one species of Sousa, S. chinensis, in the IndoPacific.

Shortbeaked common dolphins (Delphinus delphis) are not yet known to occur in Chinese waters. All of the confirmed records are of exceedingly long beaked animals and were referred to as longbeaked common dolphin (D. capensis) provisionally. ${ }^{13)}$

\section{Morphology}

Extensive anatomical and histological studies on Lipotes were made in the 1970 s and 1980 s. $^{21)}$ Papers on the structure of all the organ systems except the circulatory system have been published. Dimorphism was detected in body length and in skull dimension of Lipotes. ${ }^{22)}$ Maximum recorded length for females is $253 \mathrm{~cm}$ and for males $229 \mathrm{~cm}$. Maximum recorded condylobasal length for females is $650 \mathrm{~mm}$ and for males $534 \mathrm{~mm}$. The stomach in Lipotes differs in structure from all other cetacean species. ${ }^{23)}$ The forestomach is lacking, and the main stomach is divided into three compartments. The connecting channel between the main stomach and the pyloric stomach is absent. A pair of subtriangular hard plates is situated at each side of the nasal passage under the subcutaneous fat tissue in Lipotes. Three pairs of diverticula (vestibular sac, nasofrontal sac and premaxillary sac) open to the nasal passage; no accessory sac has been found. False vocal cords are present in the larynx and the vocal cords are absent.
The trachea is divided into right and left bronchi; the apical bronchus arises from the trachea in a position higher than the bifurcation of the latter two. The Yangtze River is turbid. The visibility from the surface downward is about $25-35 \mathrm{~cm}$ in April and 12 $\mathrm{cm}$ in August. A corresponding regression has taken place in the eye of Lipotes. It is smaller than that of delphinids but still functional. The total number of retinal ganglion cells counted was about $22000 .{ }^{24)}$

Study of the anatomy of Neophocaena was initiated in the 1920 s by Ping, followed by Howell. Most of the papers on the structure of digestive and respiratory systems and other organ systems were published in the $1980 \mathrm{~s}^{25)}$ The structure and function of the tubercles on the back of Neophocaena were reported by Liu. ${ }^{26)}$ A number of encapsulated nerve endings are present in the tubercular skin. Therefore, the tubercles are referred to as sensory organ rather than a structure for preventing the calf from slipping off. Nine to ten nasal sacs were recognized in Neophocaena. Measurement and enumeration of renculi and glomeruli were made and rencular structural indices were determined in the kidneys of Neophocaena. No differences were found in the mean number of glomeruli and the volume of glomeruli per gram of kidney between the samples taken from Yellow Sea specimens and Yangtze River specimens, while the mean value of the rencular structural indices for the former was higher than that for the latter. ${ }^{27)}$ The gray matter in the spinal cord in Neophocaena was divided into 10 layers; the layer division is similar to that of cat. In addition to the lateral cervical nucleus, the lateral thoracic nucleus and lateral lumbocaudal nucleus, respectively, were observed. The latter two were reported for the first time in the gray matter of the spinal cord of cetaceans. ${ }^{28)}$

Quantitative analysis of fiber numbers and fiber diameter spectra of optic, cochlear and vestibular nerves in $L$. vexillifer, $S$. chinensis, $N$. phocaenoides, T. truncates, and $D$. capensis were provided by Gao and Zhou. All the fibers are myelinated. The maximum diameter of the myelinated fibers of the cochlear nerve in Neophocaena were $59.4 \mathrm{i} \mathrm{m}$, the largest diameter recorded for the cranial nerve, or any other nerve, among the vertebrates. ${ }^{29)}$

\section{Endangered species and populations}

The baiji (L. vexillifer) inhabits the middle and lower reaches of the Yangtze River and is the most endangered of dolphins. It is listed under the $C R$ category in the "2000 IUCN Red List of Threatened Species". The earliest appeal to the conservation of 
the baiji was made by Zhou in 1982 . He estimated that only about 400 baiji remained in the Yangtze River and wrote that the rarest toothed whale was at the brink of extinction. ${ }^{30)}$ Population status studies made by the Chinese scientists in the years since 1982 have consistently indicated further declines in the wild baiji population. ${ }^{31-33)}$ Results of the whole-range surveys conducted in 1997, 1998 and 1999 indicated that the scale of population figures may have shifted from the low hundreds to the low tens by the end of the $20^{\text {th }}$ Century.

The Yangtze population of the finless porpoise ( $N$. p. asiaeorientalis) is sympatric with the baiji and is the only known freshwater stock. It is listed under the EN category in the "2000 IUCN Red List of Threatened Species". The population of the Yangtze finless porpoise was roughly estimated to be 2700 animals in the 1980s, and has declined in recent years. ${ }^{34)}$

In China, the Indo-Pacific hump-backed dolphin (S. chinensis) is only known from coastal waters, as far north as the mouth of the Yangtze River. Most of the records are centered around the mouths of large rivers. One of the best known populations is centered around the mouth of the Pearl River (Zhujiang). The estimate of the total population size in the Pearl River estuary is about 1,000 dolphins. ${ }^{35}$ ) The population in Xiamen waters was roughly estimated to be about 60 animals. ${ }^{36)}$ The size of the hump-backed dolphin populations in the coastal waters of Zhejiang Province and Guangxi AR have not yet been studied.

Three skeletons of gray whales (Eschrichtius robustus) were obtained off Liaoning, Zhejiang and Guangdong in the Yellow Sea, East China Sea and South China Sea between 1933 and 1954. ${ }^{37)}$ An adult female died near the coast of Zhuanghe City, Liaoning Province in December 1996; this is the only record of the gray whale in Chinese waters in the past twenty years. ${ }^{1)}$

The dugong (D. dugon) has been found in Chinese coastal waters along the coasts of Guangxi, Guangdong, Hainan and Taiwan. The dugong population declined drastically in Chinese coastal waters in the 1990s due to destruction of seaweed beds, pollution and subsistence hunting. A small group of 5 dugongs was sighted in the surveys conducted in the Beibu Gulf in 2000. The results indicated that dugongs still existed in some area in the Beibu Gulf, although their distribution and number has been greatly reduced (Zhou KY, Xu XR, Tang JS, Unpubl. Data, 2001).

The breeding population of the larga seal (Phoca largha) in the Liaodong Gulf declined drastically since the 1980s due to marine petroleum production and illegal hunting. ${ }^{38)}$

Table 2 Natural or semi-natural reserves for marine mammals in China

\begin{tabular}{llc}
\hline \multicolumn{1}{c}{ Species } & \multicolumn{1}{c}{ Locality } & $\begin{array}{c}\text { Established } \\
\text { in }\end{array}$ \\
\hline $\begin{array}{l}\text { L. vexillifer \& } N . \\
\text { p. asiaeorientalis }\end{array}$ & $\begin{array}{l}\text { Tongling, lower } \\
\text { reaches of the } \\
\text { Yangtze River } \\
\text { ditto }\end{array}$ & 1994 \\
& $\begin{array}{l}\text { Xinluo, middle } \\
\text { reaches of the } \\
\text { Yangtze River }\end{array}$ & 1992 \\
ditto & $\begin{array}{l}\text { Shishou, middle } \\
\text { reaches of the }\end{array}$ & 1992 \\
& $\begin{array}{l}\text { Yangtze River } \\
\text { Xiamen, Fujian }\end{array}$ & 1997 \\
D. duginensis* & Beihai, Guangxi & 1996 \\
P. largha* & Dalian, Liaoning & 1992 \\
\hline
\end{tabular}

*populations in Chinese waters are threatened

\section{Conservation efforts}

The Chinese government at various levels has enacted a series of laws and provisions to protect wildlife, including marine mammals, and to protect marine environment. Laws and regulations such as the Fishery Law of PRC, the Wildlife Protection Law of PRC, the Marine Environment Protection Law of PRC, etc, were promulgated. In addition, natural or semi-natural reserves have been set up to save the endangered species and populations (Table 2). The laws and regulations dealing with wildlife however have not been strictly enforced in some areas, the conservation efforts are inadequate in terms of energy and funds, and the endangered species and populations still suffer from habitat degradation. The decline of the endangered species and population continued, and the baiji is approaching extinction. Therefore, much more efforts are urgently needed to conserve the marine and freshwater mammals in Chinese waters.

\section{ACKNOWLEDGEMENTS}

I thank N. Miyazaki for inviting me to participate in the International Commemorative Symposium of the 70th Anniversary of the Japanese Society of Fisheries Science in Yokohoma and W. F. Perrin for his comments on earlier draft of the manuscript. This work was supported by National Natural Science Foundation of China, grant no. 39899400. 


\section{REFERENCES}

1. Zhou KY, Jefferson TA, Leatherwood S, Wang PL, Wang D, Chou LS. Marine Mammals of China. FAO Species Identification Guide. FAO, Rome. 2001.

2. Zhou KY, Qian WJ, Li YM. Recent advances in the study of the baiji, Lipotes vexillifer. J. Nanjing Norm. Coll. (Nat. Sci.) 1978: 8-13.

3. Zhou KY, Qian WJ, Li YM. The osteology and the systematic position of the baiji, Lipotes vexillifer. Acta Zool. Sin. 1979; 25: 58-74.

4. Barnes LG. Fossil Pontoporiid dolphins (Mammalia: Cetacea) from the Pacific coast of north America. Natural History Museum of Los Angeles County Contribution in Science, 1985; no. 363:1-34.

5. de Muizon $C$. Les relations phylogénétigues des Delphinida (Cetacea, Mammalia). Annales de Paléontologie (Vert-Invert), 1988; 74: 159-227.

6. Rice DW. Marine Mammals of the World, Systematics and Distribution. Special Publication Number 4. The Society for Marine Mammalogy, Lawrence, KS. 1998.

7. Berta A, Sumich JL. Marine Mammals: Evolutionary Biology. Academic Press. San Diego. 1999.

8. Yang G, Zhou KY. A study of the molecular phylogeny of river dolphins. Acta Theriol. Sin. 1999; 19: 1-9.

9. Yang G, Liu S, Ji GQ, Zhou KY, Bastida R, Rivero L. Sequence variation of mitochondrial $12 \mathrm{~S}$ rRNA gene and inferred molecular systematics of river dolphins. Zool. Res. 2000; 21: 425-431.

10. Cassens I, Vicario S, Waddell WG, et al. Independent adaptation to riverine habitats allowed survival of ancient cetacean lineages. Proc Natl Acad Sci USA, 2000 , 97: 11343-11347.

11. Hamilton H, Caballero S, Collins AG, Brownell RL Jr. Evolution of river dolphins. Proc R Soc London Biol Sci, 2001, 268/1466: 549-556.

12. Gao AL, Zhou KY. Geographical variation of external measurements and three subspecies of Neophocaena phocaenoides in Chinese waters. Acta Theriol. Sin. 1995; 15: $81-82$.

13. Zhou KY, Leatherwood S, Jefferson TA. Records of small cetaceans in Chinese waters: A review. Asian Marine Biology 1995; 12: 119-139.

14. Zhou KY, Qian WJ. Distribution of the dolphins of the genus Tursiops in the China seas. Aquat. Mamm. 1985; 1985: 16-19.

15. Zhou KY. Notes on two species of dolphins of the genus Tursiops in Chinese waters. Acta Hydrobiol. Sin. 1987; 7: 246-254.

16. Wang, JY, Chou LS, White BN. Mitochondrial DNA analysis of sympatric morphotypes of bottlenose dolphins (genus Tursiops) in Chinese waters. Mol. Ecol. 1999; 8: 1603-1612.

17. Wang, JY, Chou LS, White BN. Osteological differences between two sympatric forms of bottlenose dolphins (genus Tursiops) in Chinese waters. J. Zool. Lond. 2000; 252: 147-162.

18. Wang, JY, Chou LS, White BN. Differences in the external morphology of two sympatric species of bottlenose dolphins (Genus Tursiops) in the waters of China. J. Mamm. 2000; 81: 1157-1165.

19. Zhou KY, Li YM, Qian WJ, Yang GP. Notes on three species of dolphins from the south China Sea and Jiulongjiang River. Acta Oceanol. Limmol. Sin. 1980; 11: 306-313.

20. Ross, GJB, Heinsohn GE, Cockcroft VG. Humpbacked dolphins Sousa chinensis (Osbeck, 1765), Sousa plumbea (G. Cuvier, 1829) and Sousa teuszii (Kükenthal, 1892). In: Ridgway SH, Harrison R (eds). Handbook of Marine Mammals, vol. 5: The First Book of Dolphins. Academic Press. San Diego. 1994; 23-42.

21. Zhou KY. Review of studies of structure and function of the baiji, Lipotes vexillifer. In: Perrin, WF, Brownell RL Jr, Zhou KY, Liu JK (eds). Biology and Conservation of the River Dolphins. IUCN, Gland. 1989; 99-113.

22. Gao AL, Zhou KY. Sexual dimorphism in the baiji, Lipotes vexillifer. Can. J. Zool. 1992; 70:1484-1493.

23. Zhou KY, Li YM, Qian WJ. The stomach of the baiji, Lipotes vexillifer. Acta Zool. Sin. 1979; 25: 95-100.

24. Gao AL, Zhou KY. Studies on the retinal ganglion cells of Neophocaena and Lipotes. Acta Zool. Sin. 1987; 33: 316-322.

25. Zhou KY. Marine mammal studies in China. IBI Reports, 1991; 2: 11-33.

26. Liu RJ. The ultractructure and function of the tubercles on the back of Neophocaena phocaenoides in the Changiang River in China. Acta Hydrobiol. Sin. 1985; 9: 209-212.

27. Ni JY, Zhou KY. Rencular structural indices and urinary concentrating capacity of Neophocaena phocaenoides. Acta Zool. Sin. 1988; 34: 243-250

28. Wu BS. The spinal cord of finless porpoise, Neophocaena phocaenoides. Acta Theriol. Sin. 1989; 9 ; 16-23.

29. Gao GF, Zhou KY. The number of fibers and range of fiber diameters in the cochlear nerve of three odontocete species. Can. J. Zool. 1991; 69: 2360-2364.

30. Zhou KY. On the conservation of the Baiji, Lipotes vexillifer. J. Nanjing Norm. Coll. (Nat. Sci.). 1982; (4):71-74.

31. Chen PX, Hua YY. Distribution, population size and protection of Lipotes vexillifer. In: Perrin, WF, Brownell RL Jr, Zhou KY, Liu JK (eds). Biology and Conservation of the River Dolphins. IUCN, Gland. 1989; 81-85.

32. Zhou KY. Relation between human activities and marine mammals in China. IBI Rep. 1992; 3: 15-23.

33. Zhou KY, Sun J, Gao AL, Würsig B. Baiji (Lipotes vexillifer) in the lower Yangtze River: movements, numbers threats and conservation needs. Aquat. Mamm. 1998; 24: 123-132.

34. Zhang XF, Liu RJ, Zhao QZ, Zhang GC, Wei Z, Wang $\mathrm{XQ}$, Yang $\mathrm{J}$. The population of finless porpoise in the middle and lower reaches of Yangtze River. Acta Theriol. Sin. 1993; 13: 260-270.

35. Jefferson TA. Population biology of the Indo-Pacific hump-backed dolphin in Hong Kong waters. Wildlife Monographs. 2000; 144: $65 \mathrm{pp}$.

36. Liu WH, Huang ZG. Distribution and abundance of Chinese white dolphins (Sousa chinensis) in Xiamen. Acta Oceanol. Sin. 2000; 22: 95-101.

37. Wang PL. Distribution of the gray whale off the coast of China. Acta Theriol. Sin. 1984; 4: 21-26.

38. Wang ZM, Wang PL. The larga seal. Ocean Press, Beijing, 1990. 